\title{
KESENIAN GENJRING RONYOK SEBAGAI SUMBER BELAJAR SEJARAH LOKAL DI SMA NEGERI 1 KAWALI KELAS X TAHUN AJARAN 2019-2020
}

\author{
Yulia Sriningsih', Uung Runalan Soedarmo², Yadi Kusmayadi ${ }^{3}$ \\ 1,2,3Program Studi Pendidikan Sejarah, Universitas Galuh, J. R. E. Martadinata No.150, Ciamis, Indonesia \\ Email: yuliasriningsih111@gmail.com
}

\begin{abstract}
Learning resources are one of the learning components that are important enough to determine the success or failure of learning. Learning history in schools usually does not make use of historical learning resources. Inside the school, students should provide learning that requires students to get to know local history, especially local art. This study aims to determine how the use of Genjring Ronyok art in local history learning in Senior High School 1 Kawali class X Social 2 and determine what obstacles are faced by history teachers and students in utilizing Ronyok Genjring art at Senior High School 1 Kawali. The method used in this study is the historical method with a qualitative approach. This method includes several stages, namely topic selection, source collection, verification, interpretation or interpretation, writing. The results showed that by using the Genjring Ronyok art in local history learning at Senior High School 1 Kawali students could become more active and creative in the learning process and students were more aware of local arts in their area. The obstacles faced are limited time, difficulty in licensing and the location of Genjring Ronyok art.
\end{abstract}

Keywords: Genjring Ronyok Art, Learning Resources, Local History.

\begin{abstract}
ABSTRAK
Sumber belajar adalah salah satu komponen pembelajaran yang cukup penting untuk menentukan berhasil atau tidaknya pembelajaran. Pembelajaran sejarah di sekolah biasanya kurang memanfaatkan sumber belajar sejarah. Di dalam sekolah hendaknya harus memberikan pembelajaran yang menuntut siswa untuk mengenal sejarah lokal, khususnya kesenian lokal. Penelitian ini bertujuan untuk mengetahui gambaran pemanfaatan kesenian Genjing Ronyok pada pembelajaran sejarah lokal di SMA Negeri 1 Kawali kelas X IPS 2 dan mengetahui kendala apa saja yang dihadapi guru sejarah dan siswa dalam memanfaatkan kesenian Genjing Ronyok di SMA Negeri 1 Kawali. Metode yang digunakan dalam penelitian ini adalah metode sejarah dengan pendekatan kualitatif. Metode ini mencakup beberapa tahap yaitu pemilihan topik, pengumpulan sumber, verifikasi, interpretasi atau penafsiran, penulisan. Hasil penelitian menunjukan, bahwa dengan pemanfaatan kesenian Genjring Ronyok pada pembelajaran sejarah lokal di SMA Negeri 1 Kawali peserta didik dapat menjadi lebih aktif dan kreatif dalam proses pembelajaran dan siswa lebih mengetahui kesenian lokal di daerahnya. Adapun kendala yang dihadapi adalah keterbatasan waktu, sulitnya perizinan dan tempat kesenian Genjing Ronyok.
\end{abstract}

Kata Kunci : Genjring Ronyok, Sumber Belajar, Sejarah lokal.

Cara sitasi: Sriningsih, Y., Soedarmo, U. R., \& Kusmayadi, Y. (2021). Kesenian Genjring Ronyok Sebagai Sumber Belajar Sejarah Lokal di SMA Negeri 1 Kawali Kelas X Tahun Ajaran 2019-2020. J-KIP (Jurnal Keguruan dan IImu Pendidikan), 2 (1), 115-122. 


\section{PENDAHULUAN}

Pendidikan sebagai proses pembelajaran nyata telah dialami manusia sejak dilahirkan dan berlangsung terus menerus sepanjang kehidupan. Melalui pendidikan, manusia mampu untuk mengembangkan potensi diri serta kepribadiannya menuju kedewasaan dan kemandirian. Pendidikan akan membuat manusia selalu berusaha mengembangkan dirinya sehingga mampu menghadapi setiap perubahan yang terjadi akibat adanya kemajuan ilmu pengetahuan dan teknologi (Hasanah, 2012).

Oleh karena itu pendidikan perlu mendapat perhatian terutama pendidikan yang berlangsung di sekolah. Pendidikan yang berkualitas dapat mencetak sumber daya manusia yang berkualitas. Dalam pendidikan di sekolah merupakan pendidikan formal yang diharapkan dapat memberikan pengetahuan yang diperlukan untuk pembentukan dan pengembangan pribadi siswa. Usaha untuk meningkatkan mutu atau kualitas pendidikan diawali dengan peningkatan kualitas proses pembelajaran yang ada di sekolah (Sanjaya, 2015).

Proses pembelajaran adalah proses yang didalamnya terdapat kegiatan interaksi antara guru-siswa dan komunikasi timbal balik yang berlangsung dalam situasi edukatif untuk mencapai tujuan belajar. Guru harus kreatif dan inovatif dalam menerapkan strategi pembelajaran sehingga siswa mampu menggunakan kemampuan berpikir tingkat tinggi (Afifah, et. al. 2020). Dalam proses pembelajaran, guru dan siswa merupakan dua komponen yang tidak bisa dipisahkan. Di dalam pembelajaran di sekolah selain komponen tersebut terdapat juga komponen yaitu sumber belajar.

Sumber belajar adalah salah satu komponen pembelajaran yang cukup penting untuk menentukan berhasil atau tidaknya pembelajaran. Sumber pembelajaran sejarah di SMA objek studinya kebanyakan berkaitan dengan fakta-fakta dan peristiwa masa lalu, dimana daya ingat seseorang itu terbatas pada buku. Begitu pula siswa yang sering di berikan tugas-tugas oleh guru mata pelajaran sejarah acapkali menjadikan buku teks sebagai sumber belajar (Supriatna, 2013).

Pembelajaran sejarah di sekolah biasanya kurang memanfaatkan sumber belajar sejarah. Pembelajaran di kelas biasanya guru masih mendominasi pembelajaran dengan metode ceramah maupun media gambar dan konvensional lainnya. Dan materi sejarah biasanya mengharuskan siswa menghafal yang terdapat di dalam buku. Dalam hal itu pendidik atau guru harus mampu menggunakan sumber belajar yang menuntut siswa turut serta aktif dalam pembelajaran di kelas.

Dalam sekolah hendaknya harus memberikan pembelajaran yang menuntut siswa untuk mengenal sejarah lokal atau sejarah kebudayaan dan kesenian. Kesenian merupakan salah satu isi kebudayaan manusia secara umum, karena kesenian, tidak dapat dilepaskan dari konteks kebudayaan yang menjadi kesatuannya. Keterkaitan ini disebabkan oleh kesenian merupakan salah satu diantara unsur kebudayaan yang bersifat universal. Dengan mengajarkan siswa terhadap kesenian lokal diharapkan siswa mampu mengenal kesenian-kesenian daerah yang termasuk kedalam sejarah lokal dan siswa dapat memahami sejarah lokal tersebut sebagai pengetahuan.

Di Kabupaten Ciamis dikenal sebuah kesenian yang dinamakan kesenian Genjing Ronyok yang terdapat di Dusun selapajang di Desa Kawali. Kesenian Genjing Ronyok adalah kesenian tradisional yang sudah ada sejak Islam mulai berkembang di Desa Kawali. Kesenian Genjring Ronyok ini merupakan sebuah hasil kebudayaan yang bernilai luhur dalam masyarakat, karena nilai dan fungsi yang ada dalam kesenian ini bisa dijadikan pedoman dalam kehidupan sehari-hari. Kesenian Genjring Ronyok ini berisikan sholawat-sholawat serta syair-syair Islam dan kesenian ini selalu digunakan ketika ada acara-acara besar yang sifatnya lokal maupun nasional, acara hajatan dan hari-hari besar (Sumiati, 2015).

Kesenian Genjing Ronyok bisa diterapkan dalam pembelajaran untuk mendekatkan siswa dengan kesenian lokal daerah dan khususnya pembelajaran sejarah lokal. Dalam pembelajaran sejarah khususnya sejarah lokal, terdapat beberapa tantangan yang dihadapi oleh guru, meliputi terbatasnya sumber sejarah, alokasi waktu, dan kurangnya ide inovatif dalam memfasilitasi peserta didik. Rendahnya budaya literasi sejarah lokal merupakan salah satu permasalahan yang harus 
diatasi oleh para guru dan peneliti. Dengan adanya tantangan tersebut maka pendidik atau guru harus menggunakan metode yang membuat siswa melihat langsung kesenian ataupun menggunakan media audiovisual kesenian tersebut agar membuat siswa melihat secara lebih jelas dan paham dalam proses pembelajaran.

Kesenian Genjing Ronyok sangat baik dan memungkinkan dalam proses pembelajaran sejarah, hal ini dikarenakan nilai-nilai luhur dapat hilang jika tidak ada upaya dalam menjaga dan meneruskan penyampaian pada generasi muda. Upaya yang dilakukan oleh guru adalah memberikan tugas kepada siswa melakukan pengamatan atau pembelajaran yang berada di lingkungan sekitar. Seperti halnya mempelajari kesenian Genjring Ronyok. Dengan mempelajari kesenian Genjring Ronyok akan membuat siswa mengetahui bahwa ada kesenian di daerahnya yang harus mereka lestarikan.

Dalam proses pembelajaran segala bentuk strategi dan media sangat mempengaruhi keberhasilan akhir. Penggunaan strategi yang mengarah pada model pembelajaran active learning akan berdampak pada kemandirian dan keaktifan siswa. Begitu pula dengan penggunaan sumber belajar yang sesuai dengan kebutuhan dan dapat diterima serta dipahami oleh peserta didik secara otomatis dapat berfungsi secara maksimal. Salah satu bentuk dari media pembelajaran dengan cara mengajarkan siswa pada kesenian lokal yaitu kesenian Genjring Ronyok.

Pengajaran sejarah lokal berupa kesenian Genjing Ronyok memberikan kesempatan untuk mendapatkan pengalaman dan informasi sejarah sehingga mampu meningkatkan kesadaran sejarah lokal. Rendahnya kesadaran sejarah lokal salah satunya dikarenakan penggunaan buku teks yang tidak sesuai dengan kebutuhan, ketersediaan sumber belajar sejarah lokal, dan belum adanya upaya baik dari pihak guru, sekolah, dan masyarakat dalam mengintegrasikan sejarah dari suatu daerah ke dalam pembelajaran.

Materi yang berkaitan dengan kebudayaan khususnya kesenian lokal tradisional bisa diajarkan dengan cara melihat langsung kesenian yang sedang dimainkan, video dokumentasi maupun menayangkan berupa power point mengenai kesenian tersebut, lalu dijelaskan oleh guru bagaimana sejarahnya dengan cara menggunakan metode yang menuntut siswa aktif bukan hanya dengan metode ceramah. Diharapkan dengan mempelajari kesenian Genjring Ronyok siswa di SMA Negeri 1 Kawali akan lebih mengenal kesenian tersebut yang berasal dari daerahnya, dan siswa menjadi lebih mengenal kembali nilai warisan luhur kebudayaan lokal setempat.

Berdasarkan penjelasan tersebut, penelitian ini bertujuan untuk mengetahui bagaimana kesenian Genjing Ronyok dalam proses pembelajaran sejarah di SMA Negeri 1 Kawali yang akan memberikan pengetahuan sejarah lokal berupa kesenian Genjring Ronyok bagi siswa.

\section{METODE PENELITIAN}

Metode yang dipandang sesuai dengan pokok permasalahan penelitian ini dan juga sesuai dengan tujuan yang ingin dicapai adalah pendekatan kualitatif dengan metode sejarah. Adapun langkah-langkah dalam penelitian ini sebagaimana yang di ungkapkan oleh Kuntowijoyo (2005) langkah-langkah tersebut, yaitu (1) pemilihan topik, (2) pengumpulan sumber, (3) verifikasi (kritik sejarah), (4) interpretasi, (5) penulisan. Pengambilan data dan sumber data dalam penelitian Kesenian Genjring Royok Sebagai Sumber Belajar Sejarah Lokal Di SMA Negeri 1 Kawali Tahun Ajaran 2019/2020 ini dilakukan melalui wawancara. Disamping itu penulis berupaya untuk mengumpulkan data lain dari berbagai literatur yang ada di perpustakaan pemerintah daearah Kabupaten Ciamis. Teknik yang digunakan dalam proses pengumpulan data yang diperlukan penelitian ini meliputi: (1) studi pustaka; dan (2) studi lapangan, yang terdiri dari (a) teknik observasi, (b) teknik wawancara atau interview. 


\section{HASIL DAN PEMBAHASAN}

\section{Pemanfaatan Kesenian Genjring Ronyok dalam Pembelajaran Sejarah Lokal di SMA Negeri 1 Kawali.}

Peneliti melakukan observasi dengan posisi observasi nonpartisipan, peneliti hanya mengamati dan mencatat secara sistematis komunikasi yang dilakukan dalam pembalajaran sejarah di kelas $X$ IPS 2 SMA Negeri 1 Kawali antara guru mata pelajaran sejarah dengan siswa di kelas dan tempat kesenian Genjing Ronyok. Dalam pembelajaran sejarah dengan memanfaatkan kesenian Genjring Ronyok sebagai sumber sejarah lokal di SMA Negeri 1 Kawali, guru terlebih dahulu harus membuat Rencana Pelaksanaan Pembelajaran (RPP) yang mengacu pada Kurikulum 2013.

Peneliti melihat pembelajaran sejarah yang dilakukan guru sejarah dan siswa kelas X IPS 2 dalam upaya melakukan pembelajaran yang mengimplementasikan metode sejarah dan sekaligus melakukan inquiri dalam mengetahui, memahami dan menginformasikan pengetahuan yang ingin dicapainya dalam kegiatan tahap-tahapan sebagai berikut :

Tahapan pertama peneliti melihat guru mendesain Rencana Pelaksanaan Pembelajaran (RPP) dengan menghubungkan materi sejarah yang sesuai dengan buku teks pembelajaran sejarah yaitu materi penyebaran agama Islam dengan Kompetensi Dasar 3.8 menganalisis berbagai teori tentang proses masuk dan berkembangnya agama Islam di Indonesia.

Tahap kedua peneliti melihat guru dan siswa melakukan pembelajaran sejarah dengan mengujungi tempat kesenian Genjing Ronyok. Teknik yang digunakan oleh siswa diantaranya dengan melakukan teknik observasi, wawancara dan dokumentasi. Dalam pengumpulan data yang dilakukan melalui sumber lisan dan benda, siswa telah mencari, mendengarkan dan dapat mengumpulkan data-data yang diperlukan.

Tahapan ketiga peneliti melihat pembelajaran sejarah pada tahap terakhir yang dilakukan oleh siswa dalam menuliskan semua hasil observasi dan wawancara yang dilakukan menjadi sebuah laporan kelompok sebagai hasil pembelajaran yang akan di diskusikan pada pembelajaran sejarah di dalam kelas X IPS 2.

Melalui pembelajaran kontekstual kurikulum 2013 dalam pembelajaran dengan pendekatan saintifikasi, guru telah memberikan pembelajaran yang melibatkan siswa aktif terlibat dalam pembelajaran. Salah satu aktivitas guru dalam kegiatan pembelajaran yaitu menyediakan pembelajaran sejarah lokal berupa Genjring Ronyok untuk mendorong siswa mengetahui kesenian lokal di daerah Selapajang, sebab guru bukan satu-satunya subjek pembelajaran melainkan lingkungan sekolah dapat dijadikan sebagai sumber pembelajaran.

\section{a. Desain Pembelajaran}
1) Hasil Observasi
2) Hasil Wawancara

b. Tahapan Pembelajaran

\section{Pertemuan Pertama}
1) Persiapan
2) Kegiatan Inti
3) Penutup

Pertemuan Kedua

1) Persiapan

2) Kegiatan Inti

3) Penutup

\section{Pertemuan Ketiga}
1) Persiapan
2) Kegiatan Inti
3) Penutup 


\section{PEMBAHASAN}

\section{Pemanfaatan Kesenian Genjring Ronyok dalam Pembelajaran Sejarah Lokal di SMA Negeri 1 Kawali}

Berdasarkan observasi yang peneliti lakukan pada pembelajaran sejarah yang dilaksanakan di SMA Negeri 1 Kawali kelas X IPS 2 dengan memanfaatkan kesenian Genjring Ronyok sebagai sumber belajar sejarah lokal, guru harus membuat Rencana Pelaksanaan Pembelajaran (RPP) terlebih dahulu yang mengacu pada kurikulum 2013.

Dari ketiga sumber belajar sejarah yang dipergunakan yaitu; guru, LKS, dan buku teks, dimana guru memberikan dampak bagi siswa apabila cara mengajar guru terpaku berbicara tanpa memberikan cara mengajar yang menyenangkan oleh karena itu, perlu adanya sumber belajar sejarah yang lain untuk membuat siswa berpikir kritis dan analis.

Salah satu sumber belajar yang lain adalah mengeksplor tempat-tempat yang ada disekitar terutamanya tempat kesenian Genjing Ronyok yang ada di Selapajang, karena dalam pemanfaatan itu sebagai sumber belajar sejarah yang dapat memotivasi belajar siswa, mendukung pencapaian kompetensi siswa dan mendukung program pengajaran yang melibatkan aktivitas peneliti bidang studi pelajaran sejarah. Pengadaan tempat kesenian Genjring Ronyok sebagai sumber belajar sejarah lokal di karenakan ekonomis menyangkut dana, relevansi dengan materi dan kompetensi yang di hendaki mudah tercapai. Selain itu juga, efisien, mudah dan tepat dalam pencapaian kompetensi yang ingin di capai oleh siswa serta bernilaikan bagi proses pembelajaran studi bidang pelajaran sejarah contohnya yaitu dengan memperkenalkan kesenian-kesenian yang ada di sekitarnya tepatnya kesenian Genjring Ronyok dimana peneliti melakukan analisis terhadap pembelajaran sejarah yang dilakukan dalam tiga tahap pertemuan di kelas X IPS 2 SMA Negeri 1 Kawali

Pada pertemuan pertama, pembelajaran menggunakan metode ceramah dan terpaku pada buku teks. Dalam proses pembelajaran tersebut didik lebih banyak memperhatikan saja dibandingkan aktif dalam pembelajaran.

Pada pertemuan kedua, peserta didik diajak ke lokasi yang berkaitan dengan sejarah lokal dengan melihat langsung bagaimana sejarah lokal berupa kesenian lokal dimainkan. Terjadi beberapa perbedaan dengan pertemuan sebelumnya, dimana pada pertemuan kedua peserta didik terlihat antusias dalam pembelajaran dan terjadi interaksi aktif berupa pertanyaan-pertanyaan yang diajukan oleh peserta didik kepada narasumber, sehingga kegiatan pembelajaran menjadi sangat menarik.

Pada pertemuan ketiga, peserta didik diarahkan untuk diskusi mengenai hal-hal yang telah didapat dari observasi ketempat kesenian Genjring Ronyok, kemudian dipresentasikan. Setelah di presentasikan pembelajaran dengan menggunakan kesenian Genjring Ronyok, selain memberikan dampak baik terhadap peserta didik juga bisa meningkatkan pengetahuan dan rasa memiliki masyarakat terhadap tradisi Genjing Ronyok, memotivasi generasi muda agar memiliki keinginan untuk terus melestarikan seni tradisi khususnya Genjing Ronyok, berkeinginan mempertahankan kepercayaan pemerintah kabupaten terdahulu yang menjadikan kesenian Genjring Ronyok sebagai ikon seni tradisi dan meneruskan salah satu cara penyebaran Islam oleh orang tua terdahulu agar sejarah penyebaran agama Islam tetap di ingat oleh seluruh lapisan masyarakat.

Pemanfaatan kesenian Genjring Ronyok dapat dilakukan dengan kegiatan observasi yang dilakukan siswa dengan anjuran dari guru untuk ke tempat kesenian Genjring Ronyok. Kegiatan ini dapat dijadikan sebagai munculnya suatu gagasan dan ide baru yang dapat merangsang siswa untuk menggunakan kemampuannya dalam berfikir kritis scara optimal, realisasi pemanfaatan kesenian Genjing Ronyok sebagai sumber belajar sejarah lokal bagi siswa kelas X SMA Negeri 1 Kawali adalah dengan melakukan kunjungan ke tampat kesenian Genjring Ronyok, tujuan ini agar siswa dapat melihat siswa secara langsung seperti apa kesenian itu. Dampak pembelajaran sejarah dengan memanfaatkan kesenian Genjing Ronyok sebagai sumber belajar sejarah lokal dirasakan 
oleh guru sejarah yaitu ibu Vina Agrestia S.,Pd.,M.,Pd. bahwa pembelajaran sejarah yang berlangsung di luar ruangan kelas di tempat kesenian Genjing Ronyok itu membuat siswa lebih termotivasi dan semangat dalam menerima materi pelajaran sejarah dengan melihat langsung kesenian di mainkan sehingga berpengaruh pada pengetahuan siswa tentang bagaimana penyebaran agama Islam pada jaman dahulu.

\section{Kendala Guru Sejarah dan Siswa dalam Memanfaatkan Kesenian Genjring Ronyok di SMA Negeri 1 Kawali.}

Pengunaan kesenian Genjring Ronyok sebagai sumber belajar sejarah lokal merupakan salah satu sumber yang baik dalam mengembangkan kreatifitas siswa dan mempermudah memahami sumber sejarah yang diperoleh dari buku teks ataupun guru. Pemanfaatan kesenian ini tidak begitu saja diterima maupun diterapkan dalam pembelajaran sejarah. dalam menggunakan kesenian Genjing Ronyok sebagai sumber belajar sejarah lokal terdapat beberapa kendala yang masih harus dihadapi baik oleh siswa maupun guru dengan didasarkan beberapa alasan.

Adapun kendala dan upaya yang dicapai dalam rangka kegiatan memanfaatkan kesenian Genjing Ronyok sebagi sumber belajar sejarah yaitu :

\section{a. Keterbatasan Waktu}

Berdasarkan penuturan dari Vina Agrestiar S.,Pd.,M.,Pd. menjelaskan kendala umum yang dihadapi dalam kegiatan belajar dengan meanfaatkan kesenian Genjring Ronyok sebagai sumber belajar sejarah lokal adalah masalah keterbatasan waktu. Hal ini dikarenakan keterbatasan waktu dalam jam pelajaran sejarah yang hanya $2 \times 45$ menit (2 jam pelajaran), dan itu kurang memadai untuk melakukan kunjungan keluar sekolah khususnya ke tempat kesenian Genjing Ronyok. Upaya yang dapat dilakukan untuk mengatasi keterbatasan waktu yaitu dengan menggunakan waktu lain, misalnya pada hari libur sekolah, agar siswa dapat leluasa dalam melakukan kegiatan belajar di tempat kesenian Genjring Ronyok.

\section{b. Perizinan}

Kunjungan yang dilakukan oleh siswa harus melihat waktu yang tepat dimana tidak mengganggu jam pelajaran yang lain. Disamping itu, perizinan juga menjadi kendala dalam melakukan kunjungan ke tempat kesenian-kesenian yang lain. Penyebabnya adalah tidak terdapat himbauan dari dinas pendidikan dan kebudayaan tentang pemanfaatan kesenian Genjring Ronyok sebagai sumber belajar sejarah sehingga, untuk mendapatkan izin dari pihak sekolah untuk melakukan kunjungan sangat sulit karena beranggapan pembelajaran sejarah lebih efektif dilakukan dalam kelas.

Kesenian Genjring Ronyok tersebut tidak secara langsung dapat terlaksana, karena terdapat berbagai kendala yang harus dihadapi. Kendala tersebut antara lain adalah; tempat Kesenian Genjring Ronyok, tempat kesenian Genjing Ronyok yang kecil tidak cukup untuk menampung semua siswa yang akan belajar di dalam tempat kesenian Genjring Ronyok itu.

\section{KESIMPULAN}

Pemanfaatan kesenian Genjing Ronyok dalam pembelejaran sejarah lokal di SMA Negeri 1 Kawali peneliti terlebih dahulu bertanya kepada guru untuk menyesuaikan judul penelitian peneliti dengan RPP yang mengacu pada Kurikulum 2013. Peneliti melihat pembelajaran sejarah yang dilakukan guru sejarah dan siswa kelas X IPS 2 dalam kegiatan tahapan-tahapan sebagai berikut; tahapan pertama peneliti melihat guru mendesain Rencana Pelaksanaan Pembelajaran (RPP) dengan menghubungkan materi sejarah yang sesuai dengan buku teks pembelajaran sejarah yaitu materi penyebaran agama Islam, tahapan kedua peneliti melihat guru dan siswa melakukan pembelajaran sejarah dengan mengujungi tempat kesenian Genjring Ronyok. Teknik yang digunakan oleh siswa diantaranya dengan melakukan teknik observasi, wawancara dan dokumentasi, tahapan ketiga peneliti melihat pembelajaran sejarah pada tahap terakhir yang dilakukan oleh siswa dalam menuliskan semua hasil observasi dan wawancara yang dilakukan 
menjadi sebuah laporan kelompok sebagai hasil pembelajaran yang akan di diskusikan pada pembelajaran sejarah di dalam kelas X IPS 2.

Kendala Guru Sejarah dan siswa dalam Memanfaatkan Kesenian Genjring Ronyok di SMA Negeri 1 Kawali diantaranya keterbatasan waktu dan perizinan dari pihak sekolah, penyebabnya adalah tidak terdapat himbauan dari dinas pendidikan dan kebudayaan tentang pemanfaatan kesenian Genjing Ronyok sebagai sumber belajar sejarah sehingga, untuk mendapatkan izin dari pihak sekolah untuk melakukan kunjungan sangat sulit karena beranggapan pembelajaran sejarah lebih efektif dilakukan dalam kelas.

\section{REKOMENDASI}

Guru diharapkan lebih maksimal lagi dalam pelaksanaan pembelajaran dengan kesenian Genjing Ronyok sebagai sumber belajar sejarah lokal karena pembelajaran berbasis observasi atau berkunjung sebagai media pembelajaran dapat mendukung pelaksanaan pembelajaran sejarah yang lebih kreatif berbasis sejarah lokal.

\section{UCAPAN TERIMAKASIH}

Penulis mengucapan terima kasih kepada guru Sejarah dan siswa kelas X IPS 2 di SMA Negeri 1 Kawali yang telah mendukung terhadap penelitian ini.

\section{DAFTAR PUSTAKA}

Afifah, A. N., Ilmiyati, N., \& Toto. (2020). Pengaruh Model Project Based Learning (PjBL) dengan Pendekatan STEM Terhadap Penguasaan Konsep dan Keterampilan Berpikir Kritis Siswa. J-KIP (Jurnal Keguruan dan IImu Pendidikan), 1 (2), 33-40.

Hasanah, A. (2012). Pengembangan Profesi Guru. Bandung: CV Pustaka Setia.

Kuntowijoyo. (2005). Pengantar IImu Sejarah. Yogyakarta : Bentang.

Sanjaya, W. (2015). Kurikulum dan Pembelajaran. Jakarta: PT Fajar Interpratama Mandiri.

Sumiati, T. (2015). Kesenian Genjring Ronyok Di Desa Kawali, Ciamis. Skripsi UIN Yogyakarta [tidak diterbitkan].

Supriatna, E. (2013). Buku Teks Sebagai Sumber Pembelajaran Sejarah Untuk Menumbuhkan Berpikir Kritis Dan Integratif Siswa Di SMA. Jurnal Pendidikan IImu Sosial Universitas Indonesia. 
